\title{
Radicalism in Islam: The Politicization of The Mahdawiyah Hadith Among The Mahdi Movement
}

\author{
Muhammad Rikza Muqtada \\ IAIN Salatiga \\ mrmcandi@gmail.com
}

Abstract: Mahdism, or the belief in the resurrection of the eschatological figure of the Mahdi remains important in Islam today. This belief, legitimated by the mahdawiyyah hadith, has allowed many individuals throughout Islamic histories to claim themselves to be the Mahdi, as well as to carry out a radical strand of Islamic movement in order to support their claim. Using a historical method, this paper studies the history and development of mahdism, along with their interpretationof the mahdawiyah hadith; and analyzes the connection of such interpretation with the rise of religious radicalism. The study argues, mahdism is linked to the practices of millenarianism, formerly existed in Jewish and Christian theology. The emergence of mahdism related to the political conflict during the power transition from the Umayyad to the Abbasid dynasty. Yet, the rise of the Mahdi movement found its support from the mahdawiyyah Hadith, which are interpreted in such a way as to legitimize the radical-subversive movement of the mahdi's leaders, enabling mahdism to develop, ideologically, as a radical movement. This study concludes that mahdism is at once a religious and political movement aiming to bring back the glory of Islam. Religion becomes a legitimate and effective ideological framework of a political mission.

Abstrak: $\quad$ Mahdisme, atau keyakinan akan kebangkitan sosok eskatologis Imam Mahdi, tetap penting dalam Islam saat ini. Keyakinan ini, yang dilegitimasi oleh hadis-hadis mahdawiyyah, telah memungkinkan banyak individu di sepanjang sejarah Islam untuk mengklaim diri mereka sebagai Imam Mahdi, serta melakukan serangkaian gerakan 
Islam radikal untuk mendukung klaim mereka. Melalui metode historis, artikel ini mengkaji sejarah dan perkembangan mahdisme, beserta interpretasi mereka terhadap hadis Mahdawiyah; dan menganalisis hubungan interpretasi tersebut dengan munculnya radikalisme agama. Studi ini berpendapat, mahdisme terkait dengan praktik millenarianisme, yang sebelumnya ada dalam teologi Yahudi dan Kristen. Munculnya mahdisme terkait dengan konflik politik selama transisi kekuasaan dari Bani Umayyah ke dinasti Abbasiyah. Namun, kebangkitan gerakan Mahdi mendapatkan dukungannya dari hadishadis mahdawiyyah, yang ditafsirkan sedemikian rupa untuk melegitimasi gerakan subversif radikal dari para pemimpin Mahdi, memungkinkan mahdisme berkembang, secara ideologis, sebagai gerakan radikal. Studi ini menyimpulkan bahwa mahdisme merupakan gerakan agama sekaligus politik yang bertujuan untuk mengembalikan kejayaan Islam. Agama menjadi kerangka ideologis yang sah dan efektif dari misi politik.

Keywords: Radicalism, Islam, Politicization, Mahdawiyyah Hadith, Mahdi Movement

\section{A. Introduction}

Milleniarism ${ }^{1}$ is a common belief in every religion. The milleniarian belief in Islam was born out of the mahdi movement, deeply rooted in early years of the formative periods of Islamic theology. Ahmad Amin said, the popularity of the mahdism began during the transition of power from the Umayyad dynasty to the Abbasid dynasty. In the political contest between the two dynasties, the Ahl al-Bayt groups, those who identified themselves to be predecessors of the prophet, appeared as the oppressed and defeated third party. Therefore, leaders of the opposition group deliberately presented the so-called mahdawiyyah hadith, offering an utopian thought that the victory would in the end be under the leadership of their descendants, whom they called the Mahdi (the Mahdi). ${ }^{2}$

However, the existence of mahdism has an epistemic problem. Mahdism does not have strong legitimacy in the Qur'an and Sahịain (Ṣahịh al-Bukhārī dan Șahịh Muslim). Ibn Khaldun (d. 1406 AD) had

\footnotetext{
${ }^{1}$ The belief by a religious, social, or political group or movement in the coming of fundamental transformation in society.

${ }^{2}$ Ahmad Amin, al-Mahdi wa al-Mahdawiyyah (Cairo: Muassasah Handawi li alTa'lim wa al-ŚSaqafah, 2012), p. 5 and 11.
} 
pointed out this problem earlier in his al-Muqaddimah. He said mahdism in Islam was constructed only by 25 mahdawiyyah hadith, and each hadith had an authenticity problem. Some transmitters of the hadith were indicated tasayyu' (Shi'a fanaticism). ${ }^{3}$

Mahdi movements are often identified as radical-subversive movements. Therefore, the phenomenon of the emergence of various mahdi movements in various parts of the world triggers some researchers' curiosity. The research anthology edited by Sylvia L. Thrupp shows that Mahdi movement exists in primitive societies in various regions, such as in most of African areas, the Middle East, Small Europe and East Asia. These movements were always preceded by a political crisis that led to the emergence of messianic hope or the presence of a revolutionary savior. The fundamental elements in the Mahdi movement are crises, charismatic leadership (Prophets/Priests/Imams), oppressed (deprived) communities, ideologies and sacred texts, while the goal to achieve is revivalism. ${ }^{4}$

The Mahdi movement is not only held in one religious tradition. Franz Delitzsch in his research, Messianic Prophecies in Historical Succession, showed the existence of messianic narratives in the Jewish and Christian tradition. Delitzsch said that the prophecy found in each of the classic manuscript always contained about future predictions and the concept of salvation. Such ideas are always related to political contestation, which bring salvation issues in every political succession. The doctrination of this idea is always under the supervision of religious authorities. ${ }^{5}$

The Mahdi movement model is also found in the Muslim community. David Cook in his research, Contemporary Muslim Apocalyptic Literature, says that narratives about Mahdism throughout

${ }^{3}$ Abu Zaid Abdur Rahman Ibnu Muhammad Ibnu Khaldun, Al-Muqaddimah Li Ibnu Khaldūn, ed. Abdullah Muhammad Darwis, vol. 1, Chapter Fī Amri Al-Fāṭimī Wa Mā Yażhabu Ilaihi al-Nās Fī Sya'nihi (Damsiq: Dār Yu'rab, 2004), p. 514-44; Laurent Murawiec, The Mind of Jihad, 1 edition (Cambridge; New York: Cambridge University Press, 2008), p. 109; David Cook, Contemporary Muslim Apocalyptic Literature, 1 edition (Syracuse, NY: Syracuse University Press, 2008), p. 9.

${ }^{4}$ Sylvia L. Thrupp, 'Impian-impian Millenial di dalam Aksi: Laporan Mengenai Diskusi Konferensi, in Gebrakan kaum Mahdi: studi tentang gerakan-gerakan keagamaan revolusioner, ed. Sylvia L. Thrupp, trans. Anas Muhyiddin (Bandung: Pustaka, 1984), p. 3 32.

${ }^{5}$ Franz Delitzsch, Messianic Prophecies in Historical Succession (New York: Charles Scribner's Sons, 1891), p. 1-8. 
history are always related to the development of conflict and violence that occurred in the Middle East, such as between Palestine-Israel, Arab relation to the USA and several other Western countries. Cook calls the narratives that caused Islam to turn into a militant apocalyptical movement that carries the anti-Christ idea. Cook further explains how radical Muslims, including al-Qa'ida group, implement this idea to their agenda. ${ }^{6}$

In today's context, the belief of the Mahdi has been strongly manifested with the emergence of radicalism movements such as al-'Utaybi from Saudi Arabia, and the Iranian Islamic revolutionary movement under the leadership of Ayatullah Khomeini who claimed to be the mandate of the Mahdi. The movement also emerges in Sudan, and the latest, ISIS under the leadership of Abu Bakar al-Baghdadi who is believed to be the holder of al-Rayah al-Süd (black flag). Mahdism has become a transnational movement very influential for Muslim-populated countries. In Indonesia, the movements emerge such as the Jama'ah Islamic movement, the Usrah movement, NII, etc. With all their radicalism and extremism, they are confrontational with the government and aim to change drastically the state's ideology into a khilafah-based ideology (an Islamic state). Their leaders are honored as 'the Mahdi' who will return the glory of Islam.

Zeki Saritoprak in The Mahdi Tradition in Islam: A SocialCognitive Approach states that Islam accepts the concept of hope (raja'). According to Durkheim (d. $1917 \mathrm{AD}$ ), such hope is what gives power to humans to create social order for a better life. The greatest hope of Muslims today is the presence of al-Mahdi al-Muntazār (awaited Mahdi). ${ }^{7}$ Therefore, this belief is called mahdism. The Mahdi is portrayed as a revolutionary figure, who will uphold God's sovereignty to change the evil world into justice one and force everyone to pledge allegiance and convert to Islam or kill them, and to restore and win the glory of Muslims.

Based on the explanation above, this paper will discuss, firstly, the history and problem of the mahdawiyyah hadith used as a basis for the movement of mahdism, and secondly, the relationship of mahdism with the rise of religious radicalism movement. This study is conducted in a descriptive method and historical approach.

${ }^{6}$ Cook, Contemporary Muslim Apocalyptic Literature..., p. 1-10.

${ }^{7}$ Zeki Saritoprak, 'The Mahdi Tradition in Islam: A Social-Cognitive Approach', Islamic Studies, 41, no. 4 (Winter 2002): p. 673-74. 


\section{B. Scope of Mahdism}

Mahdism is an ideology that expects the arrival of the Mahdi as a savior figure of Muslims when chaos occurs in the Day of Judgment. As this ideology believes in the existence of a savior in time of crisis or conflict, it is categorized into millenarianism. Millenarianism is an ideology that believes in the coming of the Savior (Messiah) to the oppressed people due to rampant tyranny of the ruling regime. Millenarianism is always interesting to discuss when crisis, chaos and destruction hit the 'world', both as a political movement and a religious movement. ${ }^{8}$ Unfortunately, the presence of millenarianism appears to be a double-faced ideology as political and religious movement that both have no difference. Religion always emerges in a political movement at the same time.'

In some comparative studies of the Mahdi movement, the millenarian movement is often found in groups or tribes whose local traditions or culture, both in the economic, psychological, organismic, ethical systems, and in their social status are disrupted by incoming foreign influences. ${ }^{10}$ These disturbances come from other groups or the ruling regime. If the disturbance has exceeded the limit and create difficulties or make the group members feel disadvantaged (deprivation), because the disturbing migrant members turned out to be better, then millenarian movements emerge as a cultural means to eliminate oppression that occurs due to social changes which is very dangerous to or degrading the status of the group. ${ }^{11}$

Some researchers say that the object of millenarianism is often found in the colonies, where the Mahdis always present their revolutionary ideology in the middle of great turbulence or in the middle of a social revolution. ${ }^{12}$ Millenarianism is used as a mode of movement of the

\footnotetext{
${ }^{8}$ Delitzsch, Messianic Prophecies in Historical Succession..., p. 5, 6 and 9.

${ }^{9}$ Al Makin, Nabi-Nabi Nusantara: Kisah Lia Eden Dan Lainnya (Yogyakarta: SUKA-Press, 2017), p. 10; Jean-Pierre Filiu, The Return of Political ..., n.d., p. 26.

${ }^{10}$ Charles Y. Glock and R. Stark, "On the Origin and Evolution of Religious Groups (1965)", in Sociological Perspective, Selected Reading, ed. Kenneth Thomson and Jeremy Tunstall (Middlesex: Penguin Education, 1979), p. 392-96; Abdul Aziz, VarianVarian Fundamentalisme Islam Di Indonesia (Jakarta: Diva Pustaka, 2004), p. 2.

${ }^{11}$ Thrupp, 'Impian-impian Millenial di dalam Aksi .... p. 5.

${ }^{12}$ Norman Chon, "Milleniarisme Zaman Pertengahan: Hubungannya dengan Studi Komparatif Gerakan-gerakan Millenarian", in Gebrakan Kaum Mahdi: Studi Tentang 
underdeveloped people who are oppressed and undergoing drastic social system changes to carry out social protests against the tyrannical ruling regime to reclaim their glory. Thus, the emergence of the mahdism movement is a kind of social protests due to political upheaval driven by ambition to seize power in political, traditional, economic, social, spiritual, moral, physical, knowledge, relations between nations, and communication.

The issue of deprivation, as what Glock and Stark says, is an internal problem of the movement whose processes are only experienced and felt by followers of the movement, and no institution is able to overcome the deprivation except the movement group. Transmission of deprivation in society takes a long time and is experienced by several generations. ${ }^{13}$ Such long time tension and anxiety are actually caused by the tradition of millenarian thought itself which makes millenarianism a hope of a perfect consolation..$^{14}$

Michael J. Brisbois defines mahdism in his thesis as follows:

"Perhaps the most direct way to define millenarianism is to describe it simply as a socio-cultural response to alienation or disenfranchisement that combines an idealized past with a desire for imminent redemption in order to create a hopeful, utopian society in the future. Such a definition is serviceable and encapsulates the most important and most salient developments in current research, but it lacks a historical or contextual grounding. Conventionally, millenarianism is most often associated with the religions of Abraham and with Christianity specifically." 15

Millenarianism is not a new ideology, but it has been dominant for a long time in classical traditions and beliefs in the history of human civilization on earth, especially in Semitic religions. Millenarianism is not an idea held by a single religious tradition but by all world religions. Brisbois again states:

Gerakan-Gerakan Keagamaan Revolusioner, ed. Sylvia L. Thrupp, trans. Anas Muhyiddin (Bandung: Pustaka, 1984), p. 49.

${ }^{13}$ Nicholas Abercrombie, The Penguin Dictionary of Sociolgy (England: The Penguin Books ltd., 1984), p. 66.

${ }^{14}$ Chon, "Milleniarisme Zaman Pertengahan ..., p. 29-30.

${ }^{15}$ Michael J Brisbois, 'Millenarian Moderns: A Study of Utopian Desire' (University of Chalgary, 2013), p. 12. 
... millenarianism is not limited to a single religious tradition, but is transhistorical and transnational. ${ }^{16}$

Islam is a religion that is inherent with millenarianism. Muslims always believe that in difficult situations, especially in a political chaos, a revolutionary figure will come to save them; a figure who will crush cruelty in the name of religion on earth, and who will uphold Islamic sharia over other religions. The revolutionary's name is believed to be the Mahdi, though on the other hand there is also the belief that the Prophet Isa will also descend back to the world for the same mission. Thus, idea of millenarianism in Islam is better known as mahdism.

\section{History of Mahdism and The Interpretation of The Mahdawiyyah Hadith}

1. Transmission of Mahdism into Islamic Theology

As the Qur'an does not inform the presence of the Mahdi, while the majority of Muslims believe in his arrival, it is necessary to look at the history of classical mahdism that developed in pre-Islamic times. Ideas about mahdi are found in the theology of non-Islamic religions that incidentally were born long before Islam came; only the term millenarianism is more often used to define it. Each religion expresses millenarianism differently, but substantially they almost have similarity.

History reveals that the oldest form of millenarianism that is widely known is the hope of Jewish messianic. Chapter III of the Book of Daniel, written around $165 \mathrm{BC}$ when the Maccabean revolution culminated, was a millenarian manifesto that prophesied that the Israelites would overthrow the Greek kingdom and would rule the entire world forever. Similar fantasies are often found in militant apocalypses. They were written during the war between Jews and Romans from $63 \mathrm{BC}$ to 72 $\mathrm{AD}$, such as Baruch's Apocalypses that prophesied that soon the Messiah would break Rome and would destroy every nation that had colonized Israel, and will establish a kingdom until the Day of Judgment. ${ }^{17}$ Those are the evidence of fanatics groups who sparked and led the wars between Israel and Rome. The groups are those of millenarian movement that are

\footnotetext{
${ }^{16}$ Ibid., 13.

${ }^{17}$ Chon, "Milleniarisme Zaman Pertengahan ..., p. 39.
} 
drunk on these fantasies and strongly believe that the supernatural Messiah will soon come.

Christianity, which developed from Judaism, also inherited millenarianism. Whatever Jesus might have meant when he said "the kingdom of God is almost here", many Christians from the first century to the fourth century no doubt, including famous priests such as Papias, Irenaeus, and Lactantius, wished God would fall on earth. In the Book of Revelation (XX: 4-6) ${ }^{18}$ it is mentioned that after the second coming of Christ, a messianic kingdom on earth will be established and the reins of leadership in this kingdom for a thousand years before the Day of Judgment arrives will be held. ${ }^{19}$ Both Jews and Christians assume that the Messiah will retaliate, exterminate the wicked, and glorify the believers.

Christianity is perhaps the most intensely millenarian of major faiths, and the very terminology of the millennium, especially the terms apocalypse and Armageddon, are taken from the Book of Revelation (Apokalypsis in the original Greek). The millenarianism of Judaeo-Christianity continues into Islam, creating a new series of eschatological beliefs about the future, so that each religious tradition that traces its origin to Abraham is millenarian. ${ }^{20}$

These Jewish and Christian thoughts also influenced millenarianstyle movements throughout the world. Perhaps because their influence is so broad, that a lot of blurring going into the use of concepts derived from those thoughts. The majority of world's religions are waiting for the arrival of the 'Savior' from their group which is expected to come at the end of time. The news of his arrival is stated in the prophecies contained in the respective religious scriptures and hereditary messages. Jews and Christians are waiting for the coming of the Messiah (Daniel 12: 11-12, Matthew 23: 38-39 $)^{21}$ and the presence of Ahmad, Hindus are waiting for Krishna's arrival (Saukat: 97, Mantar: 3, Saukat 137, Mantar: 7, Atharwed), ${ }^{22}$ Buddhists are waiting for Mahatma Gautama, Sikhs are waiting for the

${ }^{18}$ Drafting Team, The Holy Bible Sharif Translation (Beirut: Sharif Bible Society, 2006).

${ }^{19}$ Ibid., p. 41.

${ }^{20}$ Brisbois, "Millenarian Moderns: A Study of Utopian Desire" ..., p. 13.

${ }^{21}$ Team, The Holy Bible Sharif Translation.

${ }^{22}$ Drafting Team, 'Vedas' (the Dharmic Scriptures Team, November 2002). 
arrival of the Master, Persia (Zoroaster) is waiting for a figure from their people, and Islam is waiting for the presence of Imam Mahdi and Prophet Isa. $^{23}$

Islam is indeed one of the religions that transmits millenarianism, though it is very difficult to find its proof in the Qur'an. Millenarianism in Islam is the hope of the coming of the Mahdi, so its idea is better known as mahdism. Bob de Graaff writes:

During the first centuries of its existence, Islam exchanged many ideas with believers of both the Christian, the Jewish and the Zoroastrian faith. Among these shared ideas, were also apocalyptic visions. Even though it is hard to find apocalyptic tendencies in the Quran and only parts of the most prestigious collections of the hadith contain apocalyptic references. ${ }^{24}$

The basis for the presence of the Mahdi is found in hadith, while hadith only began to develop rapidly around two centuries after the death of the Prophet Muhammad, so it is not wrong if some academics claim that there was no mahdism at the beginning of Islam. Ideas of Mahdi are considered as the creation of people of the later generation. For me it is an early conclusion. The fact is that the Qur'an has adopted the logic of mahdism about Muhammad's presence:

And (mention) when Isa, the son of Mary, said, "O children of Israel, indeed I am the messenger of Allah to you conforming what came before me of Torah and bringing good tidings of a messenger to come after me, whose name is Ahmad." But when he came to them with clear evidence, they said, "This is obvious magic." (AlȘāf: verse 6)

The verse tells about Ahmad's presence as a revolutionary of the age. He has the same vision (being an Apostle) with Isa bin Maryam. If this verse is understood in terms of the explicit mutakallim (speaker), namely Isa bin Maryam, then the context of this conversation had already taken place at a time when Christianity was developing (1st century). Meanwhile, if understood from the chronology of the verse, the context of

${ }^{23}$ Saleh A. Nahdi, Imam Mahdi Atau Ratu Adil? (Jakarta: Arista Brahmatsya, n.d.), p. 1 .

${ }^{24}$ Bob de Graaff, History of Fanaticism: From Enlightenment to Jihad', May 2010, p. 15 . 
the conversation occurred at the time of the Prophet Muhammad. (6th century). From this, it can be understood that the idea of mahdism has indeed existed since the time of the Prophet Muhammad and previous periods, but not as the Mahdi.

In the Arab civilization of the mid-7th century (622 AD), Arab society was identified as a morally corrupt society called 'Jāhiliyyah', which is a picture of pre-Islamic societies that embrace tribalism, polytheism and paternalism, and male domination as the central government. At that time, lives were very contemptible, women were worthless, ${ }^{25}$ slavery was getting wilder, and competition between tribes never ended. ${ }^{26}$ In such conditions of crisis, the heroism of Muhammad Pbuh. is presented as messiah for the Arabs. Muhammad Pbuh. with his Islamic ideology is able to transform pre-Islamic Arab societies into global, egalitarian, civil society and integrated under the banner of Islam. Besides being mentioned in the verses of al-Șāf: 6, information about the presence of Muhammad Pbuh. as a prophet is also found in the New Testament, book of John 14:16 and 26 . Although Muhammad Pbuh. actually came, not all Arabs believed him, so he and his followers had to fight the tyranny.

Although it has been confirmed in al-Ahzab: verses 40 and 43 that Muhammad Pbuh. is the savior as well as the last Prophet, it turns out that ideas of mahdism in the hereafter, the presence of Isa b. Maryam as. or alImam the Mahdi still remain in some ideologies of Islamic sects. Apart from debates related to the unity or difference between the two figures, it is clear that the mind of some Islamic theologies still believes in the emergence of the Prophet Muhammad's sharia enforcers, even though the Qur'an does not mention the explicit proof of the presence of the Mahdi, and the return of Prophet Isa as. The Qur'an only mentions:

(Mention) when Allah said, "O Jesus, indeed I will take you and raise you to Myself and purify you from those who disbelieve and make those who follow you (in submission to Allah alone) superior to those who disbelieve until the Day of Resurrection. (Ali Imron: verse 55).

${ }^{25}$ David S. Powers, "Law and Custom in the Maghrib, 1475-1500: On the Disinheritance of Women", Law, Custom, and Statute in the Muslim World, 1 January 2007, p. 20.

${ }^{26}$ Halim Barakat, Dunia Arab; Masyarakat Budaya, Dan Negara, trans. Irfan M. Zakie (Bandung: Nusa Media, 2012), p. 40-42. 
Therefore, they do not dare to use the term Prophet. The use of the term 'Imam' is the right choice to characterize the figure of the Mahdi.

2. Mahdism' interpretation of Mahdawiyyah Hadith

Mahdism was originally presented as a socio-political movement but in its development turned into a theological-eschatological religious movement. ${ }^{27}$ The Mahdism Revolution is always under the leadership of a 'Prophet'. It turns out that he has been haunted by the shadow of revelation for years. Then he called on the poor or oppressed as his potential followers in the midst of social upheaval. ${ }^{28}$ In the Islamic prophetic history, the figure of Moses is the Messiah for the Israelites in overthrowing the Fir'aun (Pharao) regime. ${ }^{29}$ The figure of Dawud and Sulaiman is the Mesiah in saving the Israelites from the regime of King Jalut (Goliath). ${ }^{30}$ Jesus' figure also saved Israel from Roman imperialism, and Muhammad is a figure in fighting against tribalism and slavery of pre-Islamic Arabs. ${ }^{31}$

Mahdism in Islam was first rolled out by fanatic groups against Ali b. Abi Taalib and Ahl al-Bayt (mostly from the Shi'a). Their defeat and failure in the political and military field in the Umayyad dynasty, in which many of their imams were victims of politics, became an important factor that drived the birth of idea or myth about awaited Mahdi (the Mahdi alMuntazār). ${ }^{32}$ The failure of the armed uprising led by the Shi'a for more than two centuries and always being the victim of the violence of their political opponents led them to a series of suffering and deep disappointment. Such conditions make the Shi'a easily digest aqidah alimāmah, al-mahdiyyah, al-raj'ah and al-gäibah, the creation of Ibn Saba, ${ }^{33}$

${ }^{27}$ Muslih Fathoni, Paham Mahdi Syiah Dan Ahmadiyah Dalam Perspektif, 1st ed. (Jakarta: Raja Grafindo Persada, 1994), p. 3.

${ }^{28}$ Chon, 'Milleniarisme Zaman Pertengahan: Hubungannya dengan Studi Komparatif Gerakan-gerakan Millenarian', p. 51.

${ }^{29}$ Delitzsch, Messianic Prophecies in Historical Succession, p. 59-73.

${ }^{30}$ Ibid., p. 80-101.

${ }^{31}$ Ronald Albert Graff and Lambert T Dolphin, Connecting the Dots: A Handbook of Bible Prophecy (Longwood, Fla.: Xulon Press, 2010), p. 24.

${ }^{32}$ Fathoni, Paham Mahdi Syiah Dan Ahmadiyah Dalam Perspektif, 19; Filiu, 'The Return of Political Mahdism..., p. 27-28; R. Stephen Humphreys, Islamic History: A Framework for Inquiry, Revised edition (Princeton, N.J: Princeton University Press, 1991), p. 109-10.

${ }^{33}$ Fathoni, Paham Mahdi Syiah Dan Ahmadiyah Dalam Perspektif ..., p. 42-48 and 149 . 
which all of those becomes the dominant factor in accelerating the idea of waiting for the return of their priest as Messiah who will at the same time improve their social order.

After the death of Muhammad saw, Abu Bakr was inaugurated without the knowledge of Ali b. Abu Talib in $12 \mathrm{H} / 634 \mathrm{AD}$. This issue actually invited speculation about the figure among friends who are more entitled to occupy the position of the caliph. At least there are already two groups, Muhajirin and Ansar, who feel entitled to the position. On the other hand, the Banu Hasyim emerged and felt entitled to the position of the caliph, so that there are parties who want to inaugurate Ali b. Abu Țālib to be a caliph, but Ali rejected. As a result, many of Ali's supporters postponed the initiation of Abu Bakr. ${ }^{34}$ That fact is the embryo of political issues over the right of $A$ hl al-Bayt to be the caliph.

The desire to inaugurate Ali b. Abū Țālib was always delayed until the time of Usman b. Affan, in which political power of the Umayyads also began to emerge. In its history, the ancestors of the Umayyads were recorded that they hostiled the Prophet for about 20 years. This issue is increasingly burning that Ahl al-Bayt had right to better lead. After Ali $b$. Abu Talib was appointed as the caliph, the supporters of the Umayyads carried out attacks and terror to gnaw the sovereignty of Ali's leadership. The defeats of Ali's party in political diplomacy, such as daumatu al-jandal and al-tahkim (arbitrase), and the killing of Ali (41 AH/661 AD) by a Khawarij named Ibnu Muljam, increasingly hurt the supporters of Ahl alBayt. The condition was getting worse by the killing of Husayn $b$. Ali $b$. Abū TTâlib (680 AD) in the battle with Yazid b. Mu'awiyah's army in the land of Karbala. ${ }^{35}$

In this increasingly difficult condition, supporters of Ahl al-Bayt received support from the Mawälli of Persia whom once were dominated by Christians and Jews who felt dissatisfied with the control of the Umayyads. They encourage and give new directions of the socio-political movement to Ahl al-Bayt. The style of thought of Ahl al-Bayt was later influenced by Persian foreign thoughts. Thus, the direction of their political movement changed into religious movement with a familiar style. ${ }^{36}$ Such strong pressure and changes in the mindset encouraged $\mathrm{Ahl}$ al-

${ }^{34}$ Ibid., p. 18.

${ }^{35}$ Ibid., p. 24.

${ }^{36}$ Fazlur Rahman, Islam (Chicago and London: University of Chicago Press, 1977), p. 171. 
Bayt to create stimulating ideas to fight the tyranny they were suffering from in the name of religion. This is the starting point of understanding mahdism in Islam which is strongly influenced by Jewish and Persian Christian mahdism. ${ }^{37}$

R. Stephen Humphreys in Messianic Text, in the Form of the Hadith, Malähim (Apocalyptic Predictions) ${ }^{38}$ mentions that in the political transition of the Umayyad dynasty to the Abbasid dynasty, the Shi'a, as the oppressed, used mahdawiyyah hadith for their interests to continue their struggle for the right of legitimate Caliphate. Ahmad Amin in the Mahdi wa al-Mahdawiyyah said that this mahdism was instilled in the form of resistance to the Umayyad and Abbasid dynasty. ${ }^{39}$ They made a utopian ideology through hadith which say that victory is under the leadership of their descendants whom they called the Mahdi.

The Shi'a is the most fanatical in Mahdism. Many hadith about Imam Mahdi are found in the Shi'a books. For example, in al-Kāfi li alKulaini, it is mentioned:

"Al-Asbag b. Nubātah said: "I went to Amīr al-Mu'minīn, then I found him contemplating watching the ground. Then I asked, "O Amir al-Mu'minin, I see that you are watching the ground, are you attracted to it?" He said, "No, by Allah. I do not like it and even the world for a day, but I am thinking about the child who will be born from my back, the eleventh of my children, he is the Mahdi who will fill the world with justice as it has been overwhelmed by tyranny and injustice. He will experience mystery and become confused about some people who get lost and some other who get direction from him". I said, "O Amir al-Muminin, how long is the mystery and confusion?" He said, "six days, or six months, or six years". I said "and will this happen?" He said, "Yes, indeed he will be created and in fact I am knowledgeable in telling you this, Asbāg! They are the best people of this Ummah along with the best people of this bloodline". I said, "What will happen after that?" He said, "God will do whatever He want to do, for him there are

\footnotetext{
${ }^{37}$ Fathoni, Paham Mahdi Syi'ah Dan Ahmadiyah Dalam Perspektif..., p. 8 and
} 154-55.

${ }^{38}$ Humphreys, Islamic History..., p. 11; Fathoni, Paham Mahdi Syi'ah Dan Ahmadiyah Dalam Perspektif..., p. 5-7.

${ }^{39}$ Amin, al-Mahdi wa al-Mahdawiyyah ..., p. 5 and 11. 
badā'àt, irādāt, gāyāt and nihāyāt (changes in destiny, will, purpose and end)" ${ }^{40}$

While in another chapter it is mentioned that: "The Mahdi defeated them (enemies) of my religion, and showed them my country, and I stood with him before my enemies." ${ }^{31}$

Although the Shi'a are very diverse, the Imami Syiah are the largest group and are divided into two groups; First, the Shi'a Sabiyya or known as Isma'iliya or Batiniah that believe the Mahdi more realistically. One of them is 'Abdullah b. Muhammad who had succeeded in establishing a dynasty in Maghrib (Africa). Second, the group that believe that the son of Imam Hasan al-Askari (11th Shi'a priest) was the Mahdi, whom was later named Muhammad b. Hasan al-Askari. The narrations about him are all written in al-Käfi li al-Kulaini. However, the fact shows that the existence of the character is fictitious, because Imam al-Askari apparently did not have a son or was said to disappear mysteriously. ${ }^{42}$ Narrations were made to cover up his mystery. This history is also written in the book al-Käfi li al-Kulaini. This is the beginning of the ideology al-raj'ah. ${ }^{43}$ Most of the narrations are political because they show that Imam Mahdi comes from Ahl al-Bayt itself who will avenge Imam Hussein's killer.

${ }^{40}$ Abu Ja'far Muhammad bin Ya'qub bin Ishaq al-Kulaini al-Razi, Al-Kāfi Li alKulaini, ed. Ali Akbar al-Ghifari, vol. 1 (Teheran: Dār al-Kutub al-Islāmi, 1363), p. 338. This hadith has a similarity with the traditions of Sunni's scholars. See Sulaiman bin Dāwud al-Ṭayālisī al-Bașrī Abu Dāwud, Sunan Abū Dāwud, ed. Muḥammad bin Abdul Muhsin alTurkiy, Chapter al-Mahdi (Mesir: Dar Hijr, 1999), hadith number 4285; al-Hākim alNisāburi Abu Abdullah Muḥammad bin Abdullah, Al-Mustadrak 'alā al-Ṣaḥịhaini, ed. Musțafa Abdul Qadir 'Ața (Beirut: Dar al-Kutub al-Ilmiah, 1990). And in the book of Ahmad b. Hanbal and the other muhaddisin. See Abu Abdullah Ahmad bin Muhammad alSyaibāni Ibnu Hanbal, Al-Musnad al-Imām Ahmad Bin Hanbal, ed. Syu'aib al-Arna'ūte (Beirut: Mu'assasah al-Risālah, 2001), hadith number 11212; Abū Bakar al-'Abbasiy Ibnu Abi Syaibah, Muṣannaf Ibnu Abi Syaibah, ed. Kamal Yusuf al-Hūt (Riyaḍ: Maktabah alRasyd, 1409); Abu Abdullah Muhammad bin Yazid al-Qazwini Ibnu Majah, Sunan Ibnu Mājah, ed. Muhammad Fuad Abdu al-Baqi, Bab Khurūj al-Mahdi (Cairo: Dar Ihya alKutub al-Arabiyah, n.d.); Abu Abdullah Nuaim bin Hammad bin Muawiyah bin al-Haris al-Khuzai, Kitāb Al-Fitan, ed. Samir Amin al-Zuhairi, vol. 2 (Cairo: Maktabah al-Tauhid, 1412). According to the Sunni's criticus, the quality of the hadith has a hasan li gairih, because of its syawāhid.

${ }^{41}$ al-Kulaini al-Razi, Al-Kāfi Li al-Kulaini..., p. 1:11.

${ }^{42}$ Fathoni, Paham Mahdi Syi'ah Dan Ahmadiyah Dalam Perspektif..., 4.

${ }^{43}$ al-Gaibah al-Kubrā and al-Gaibah al-Sugrā. See Filiu, "The Return of Political Mahdism ..., p. 28. 
Through the mahdawiyyah Hadith, the Shi'a quickly shaped Muslims' opinion. The non-Shi'a group also fabricated mahdawiyyah Hadith with other versions according to the identity of their respective groups. Sunnis are also fanatics who believe in the arrival of the Mahdi. Interestingly, the Sunni's primary reference Hadith books, Sahin alBukhārī and Șạih Muslim, do not narrate the arrival of the Mahdi. This fact raises suspicion regarding the weaknesses of the mahdawiyyah hadith. Many hadith narrate the arrival of the Mahdi, his personalities, and his duties. In addition to the hadith narrated by the Shi'a above, from the hadith of holding the sunnah of the Prophet and the Sunnah of al-Khulafa al-Rashidun who are upon guidance (the Mahdiyyin). The word the Mahdi were then interpreted by many individuals as a person.

The word the Mahdi is used in denotative meaning in the Prophet's hadith: "It is obligatory for you to follow my sunnah and the sunnah of Khulafá al-Rasyidin al-Mahdiyyinn". The word the Mahdi then began to evolve gradually, until it referred to Ali. The Kaisaniya then developed under the leadership of al-Mukhtar b. Abi Ubaid al-Tsaqafi. $\mathrm{He}$ and his followers claimed that Muhammad b. al-Hanafiyyah was an imam, and he was the Mahdi. ${ }^{44}$

The statement shows that Muhammad b. al-Hanafiyyah as the Mahdi. He was also involved in transmission of several hadith about the Mahdi. The following is the adith saying that the Mahdi is from Ahl alBayt:

“...., from Ali ibn Abu Tālib said: Rasulullah saw. said: the Mahdi is from us, Ahl al-Bayt, Allah will fix him overnight”. ${ }^{45}$

The hadith is transmitted by Muhammad b. al-Hanafiyyah $b$. Ali. He is the son of Ali b. Abi Țâlib of his other wife, other than Fatimah alZahra. He was a person who was crowned by the Kaisaniya (from the Shi'a) as the Mahdi. ${ }^{46}$ Here it is clearly seen the involvement of figures

${ }^{44}$ Muhammad Mahjub Malik, Al-Muqāwamah al-Dākhiliyyah Li Harakati alMahdiyyah (Beirut: Dar al-Jail, 1987), p. 18; Amin, al-Mahdi wa al-Mahdawiyyah ..., p. 910.

${ }^{45}$ Ibnu Majah, Sunan Ibnu Mājah ..., p. 1367, hadith number 4085; Ibnu Hanbal, Al-Musnad al-Imām Ahmad Bin Hanbal, hadith number 645; Ibnu Abi Syaibah, Muṣannaf Ibnu Abi Syaibah, hadith number 37644.

${ }^{46}$ Amin, al-Mahdi wa al-Mahdawiyyah, h. 10. 
recognized by Shi'a in the Sunni hadith narration. Initially Muhammad b. al-Hanafiyyah was the one who benefited from the Umayyads. After Yazid b. Mu'awiyah died, Ibn al-Hanafiyyah was in conflict with Abdullah b. alZubair because Ibn al-Hanafiyyah was not willing to initiate him. Abdul Malik b. Marwan, as the ruler at the time, used Ibn al-Hanafiyyah to join him. After some time, Abdul Malik b. Marwan no longer agrred with Ibn alHanafiyyah, so he drove him away. Ibn al-Hanafiyyah felt betrayed and every time he moved, he always got the same treatment. Since then the followers of Ibn al-Hanafiyyah considered themselves the Mahdi, with which Ibn al-Hanafiyyah agreed. In its development, the incident was actually exploited by Banu Abbas, who felt they had blood relation with the family of the Prophet, to establish the Abbasid dynasty. In other word, the Mahdi was present from the Abbas family whose lineage met in Abdul Muțallib.

Next is the hadith that informs groups from the east bringing a "black flag". They carried out attacks against tyrannies on the face of the earth. They are led by 'the Mahdi'. Therefore, every Muslim is highly recommended to take allegiance to him.

“... Rasulullah Saw. said: There will be war between three (people) near your treasury, all are descendants of the caliph, and none of them succeed, then there arises a black flag from the east to fight you by means of war that has never been used even by any people then mention something that I am not able to remember - when you see it, come to take allegiance even if you have to crawl in the snow, because he is Khalifatullah al-Mahdi" ${ }^{47}$

By looking at the structure and pattern of the hadith text, we will find a variety of texts that are almost the same along with the additions to the information in it. ${ }^{48}$ Most hadith critics say that the hadith are problematic, in terms of both narrator's credibility and the matn of hadith. Those kind of hadith are believed to be the basis of Islamic radicalism movement today because they are written in a number of hadith

${ }^{47}$ Ibnu Majah, Sunan Ibnu Mājah ..., p. 1367, Hadith number 4084.

${ }^{48}$ These Hadiths was found in the book of Ibnu Mājah (4082, 4084), al-Fitan li Nu'aim bin Hammad (555, 562, 570, 584, 906, 907, 895, 1975), Muṣannaf Ibnu Abi Syaibah (37727), Musnad Ibnu Abi Syaibah (308), Musnad al-Imam Ahmad (8760), alMustadrak 'Ala al-Ṣaḥ̄haini li al-Hākim (8434), al-Maqșad al-'Ali fì Zawāidi Abi Ya’la (1826), and al-Sunan al-Kubra li al-Baihaqi (13068). 
compilation books. With various variants of the text, the "problematic hadith", borrowing the argument of David S. Powers, actually attain their status to the level of mutawātir until they are considered authentic. ${ }^{49}$ This process occurs because of consensus (ijma') among muhaddis in changing the quality of the hadith in order to be accepted.

With so many variations of hadith, quoting Ibn Hajar's opinion, Ahmad Amin says there are about 50 problematic hadith about the Mahdi. ${ }^{50}$ Amin affirms that the mahdawiyyah hadith, especially from the Shi'a, contain lies, because they are filled with strange stories and occult news about the events of their time. Moreover, there is a prediction written on the skin of an ox about what $A h l$ al-Bayt will experience, and this story is narrated by Ja'far al-Șādiq. ${ }^{51}$

However, Amin's argument was refuted by Tsamir Hasyim alAmidy through the work of al-Mahdi al-Muntażar fi Fikri al-Islām. Hasyim stated that the mahdawiyyah hadith were true and mutawatir up to the Prophet Muhammad Pbuh. He also confirmed that in the Qur'an there were already indications of the appearance of the Mahdi, as interpreted by al-Ṭabari. Likewise, in Șahịh al-Bukhāri and Șahịh Muslim actually mention their characteristics and the word imām, only not mentioning their names. $^{52}$

“... Rasulullah Pbuh. Said, "What is your attitude if Isa b. Maryam As. and your Imams come down among you?" 33

The hadith indeed mentions the coming of Ibn Maryam (Isa as.), but it does not mention the Mahdi. The explicit mention of the word the

${ }^{49}$ David S. Powers, Studies in Qur'an and Hadith: The Formation of the Islamic Law of Inheritance (London: University of Callifornia Press, 1986), p. 165-70.

${ }^{50}$ Amin, al-Mahdi wa al-Mahdawiyyah..., p. 48.

${ }^{51}$ Ahmad Amin, Duha al-Islām, vol. 3 (Cairo: Maktabah al-Nahḍah al-Miṣriyah, n.d.), p. 243.

${ }^{52}$ Tsamir Hasyim al-Amidy, al-Mahdi al-Muntazār Fi Fikri al-Islām (Markaz alRisalah, 1417), p. 19-30.

${ }^{53}$ Abi Abdillah Muhammad bin Isma'il al-Bukhārī, Al-Jāmi’al-Shahīh Li al-Imām al-Bukhārī (Beirut: Dar Ṭauq al-Najāh, 1422), hadith number 3449; Muslim bin al-Ḥajāj Abu al-Ḥasan al-Qusyairi Nisāburi, Al-Musnad al-Ṣaḥih al-Mukhtașar, Șaḥih Imam Muslim, vol. 3, Bab Al-Imārah (Beirut: Dar Ih\}yā al-Turats al-'Arabi, n.d.), hadith number $244,245,246$. 
Mahdi is found in hadith books other than Ṣahịh al-Bukhāri and Șahịh Muslim.

Shi'a and Sunni are the two largest mainstreams who have the intention to study the hadith with different hadith and their ideas influence reason of belief of several Islamic sects. However, most Islamic sects, which have quite a number of followers, have affiliations to the tradition of hadith studying of Sunni, including Ahmadiyah, ISIS and some local Islamic sects. ${ }^{54}$ Bob de Graaff states:

Although it is commonly believed that the Mahdi is a specifically Shi' ite element in Islam, throughout history there have been more Sunnite Mahdis and among current Islamic apocalyptic writings, the majority is from a Sunni point of view. ${ }^{55}$

Although the hadith of the Sunni have more influence on Islamic sects, the Shi'a who are the most fanatical in their ideology of the Mahdi. ${ }^{56}$ This is because of the influence of the long history of the Shi'a that was always in the oppression of the rulers in its territory.

Because of the codification of hadith books and the spread of the hadith, the concept of mahdism also extends its influence to various sects in Islam, such as the Fatimids, Muwahhidun, Qadiyaniya, Sudan, and Sanusiya, Ahmadiya, even the latest movements such as the Muslim Brotherhood, Wahabi, ISIS, as well as local Islamic movements in various places, such as in Java. However, not all sects accept this mahdism idea, such as the Mu'tazila and the Zaidiya.

Fazlur Rahman added that Sufis had taken a part in spreading mahdism. They are called by Quṣạs (story tellers) who are very influential in public. To attract attention, they put Israiliyat from Jew, Christian and Zoroaster into stories in the Qur'an and even adopted spiritual experiences of Hinduism and Buddhism. As mentioned earlier, these people were influenced by Christian ideas by deliberately incorporating millenarian ideas, which were manifested in the form of the Mahdi. He is a spiritual

${ }^{54}$ Because of the master books of Hadith, like as in the Kutub al-Sittah, Musnad, and Muṣannafāt, also usefully by these sects.

${ }^{55}$ de Graaff, "History of Fanaticism: From Enlightenment to Jihad"..., p. 16.

${ }^{56}$ Saritoprak, "The Mahdi Tradition in Islam: A Social-Cognitive Approach"..., p. 673-74. 
figure who will emerge later in the Day of Judgment to reestablish Islamic sharia and justice, and eradicate the opponents of God. ${ }^{57}$

\section{Mahdism and Religious Radicalism Movement}

R.S. Humphreys states that the ideology of mahdism is utopian; each group claims that their only hope of achievement that will build the best social order according to their abilities, true and legitimate order to everyone. The utopian goal is often described as reshaping of golden age that once happened but is currently lost (romanticism), or achieving dreams and aspirations ever imagined in the past. The ideology of mahdism is cyclical and demands radical changes to build an order. ${ }^{58}$ This ideology is socially deliberately created, regulated, and disseminated to control the people. The ideology is changed into a system of belief to mistify a political system while obscuring what is really happening. ${ }^{59} \mathrm{~A}$ movement must frame their ideology argument to draw people's attention and followers. ${ }^{60}$

Religion is a form of ideological frame that is legitimate and effective in socio-cultural life. ${ }^{61}$ Therefore, in every history of religious civilization, a number of religious movements are always introduced along with their ideology and basis of legitimacy. The phenomenon of religious movements emerged as a reaction to various challenges faced or as a result of pressures that came from outside. The important issue is how the challenge paves the way for the emergence of religious movements, as well as how the religious movements gain legitimacy from their religious texts. ${ }^{62}$ It seems difficult to accept if an ideology has no legitimacy from the sacred text of religion. As mentioned earlier, the arrival of the Mahdi is not written at all in the Qur'an, while the Qur'an has been codified in the form of al-

\footnotetext{
${ }^{57}$ Rahman, Islam ..., p. 132.

${ }^{58}$ Humphreys, Islamic History..., p. 148.

${ }^{59}$ Muhyar Fanani, Metode Studi Islam; Aplikasi Sosiologi Pengetahuan Sebagai Cara Pandang (Yogyakarta: Pustaka Pelajar, 2008), p. 42.

${ }^{60}$ M. Imam Aziz, "Memahami Gerakan Islam: Sebuah Agenda Untuk Indonesia", in Gerakan Sosial Islam: Teori, Pendekatan, Dan Studi Kasus, ed. Quintan Wiktorowicz (Yogyakarta: Gading Publishing, 2012), p. 6.

${ }^{61}$ Reza Wattimena, Melampaui Negara Hukum Klasik (Locke - Rousseau Habermas) (Yogyakarta: Kanisius, 2007), p. xi.

${ }^{62}$ Rusydi Sulaiman, Pengantar Metodologi Studi Sejarah Peradaban Islam (Jakarta: Raja Grafindo Persada, 2014), p. 87.
} 
Mushaf al-Usंmanī, that the only way to legitimize the mahdism ideology is through hadith text.

Mahdism theology is subtly implanted through 'sanctified' texts. The text often lulls and oppresses the realm of human consciousness, such as language. Verbalization of ideas in written text often conceives hegemonic ideology ${ }^{63}$ The proof of truth is in the birth of the text. Text has more influence than rationalization. As a result, the text of the hadith is often understood literally and rigidly. It is often used as a weapon or argument to legitimize an action. In this condition, people's reason is easily castrated by authorities who abuse the text for an interest. For this reason, it is necessary to demystify the texts and dismantle the ideological veil. ${ }^{64}$

Although the hadith about the Mahdi are problematic, many Muhaddis (hadith expert) accept these hadith, even though they are categorized as ahâd (single transmiter) or dha' if (weak). ${ }^{65}$ They interpreted the words of al-Mahdi in accordance with their interests. ${ }^{66}$ In this case, Saleh A. Nahdi states that these mahdawiyyah hadith have been confused by interested parties. The hadith which first appeared very historically is now used as a cover or legitimacy to achieve the aims and carry out the plans of certain groups. These hadith were enriched and manipulated during the breakup of Muslims and the emergence of sects within Islam that were fighting over influence and power.

As mentioned earlier, the emergence of the Mahdi is a phenomenon of the birth of a new society that wants to create political ideals. Thus, the idea must be encouraged using the spirit of group fanaticism to produce new strength to create victory. In this case, we need propagandists who have strong fanaticism towards groups. They are tasked with persuading people with issues that are easily accepted and instilling a high level of fanaticism in them. Thus, it can be understood that the setbacks and defeats suffered by Muslims are due to the weak or lost spirit of fanaticism vanishing from souls of the people.

${ }^{63}$ Thomas McCharty, Teori Kritis Jurgen Habermas, trans. Nurhadi (Yogyakarta: Kreasi Wacana, 2008), p. 272.

${ }^{64}$ Therefore, Habermas offers the Ideological Crticism that is a theory to uncover some interests behind the text, and to free the people from the confines of ideology. See F. Budi Hardiman, Kritik Ideologi; Menyingkap Pertautan Pengetahuan Dan Kepentingan Bersama Jurgen Habermas, 2nd ed. (Yogyakarta: Kanisius, 2004), p. 209-10.

${ }^{65}$ Ibnu Khaldun, Al-Muqaddimah Li Ibnu Khaldūn, 1: p. 501.

${ }^{66}$ Nahdi, Imam Mahdi Atau Ratu Adil? ..., p. 10. 
It is true that this kind of ideas seem to be in accordance with Muslim reasoning today. Very abstract Mahdism is represented for the purpose of rebuilding the Islamic world which is increasingly submerged in backwardness, poverty, and shallowness of insight in facing changing ages. It could be that mahdism in Islam is an attempt at modernization or reformation (tajdid) as practiced by the Ahmadiyya group, or as a political revenge as practiced by the majority of the Shi'a. ${ }^{67}$ While in Sudan, it is more like a State revolutionary movement. This movement has developed for years. In 1899-1956, there was a political revolution under the leadership of Abdurrahman al-Mahdi. ${ }^{68}$

In time of crisis, the millennial spirit is brought back. Franz Delitzsch added that the Mahdi group was always present for a succession of their dreams in seizing political power. At that time, there were always authorities with spiritual characteristics, so they were very influential in burning the millennial spirit. ${ }^{69}$ Michael J. Brisboris, in his dissertation, said that mahdism was identical with the modernism movement that carried the utopian ideology. This movement carried out a revolution of encompassing aspects of life of modern society, such as tradition, history, beliefs/ ideology, language, political conflict, and economics. ${ }^{70}$ Therefore, in every history of the emergence of new sects in Islam, idea of the Mahdi is very possibly brought into their theology.

The crucial impact arising from mahdism, as expressed by Ibn Khaldun, is radicalism in the name of religion:

It has been accepted by all Muslims in every epoch, that at the end of time a man from the family [of the Prophet] will without fail make his appearance, one who will strengthen Islam and make justice triumph. Muslims will follow him, and he will gain domination over the Muslim realm. He will be called the Mahdi. Following him, the Antichrist will appear, together with the subsequent signs of the Day of Judgment. After the Mahdi, [the

${ }^{67}$ Fathoni, Paham Mahdi Syi'ah Dan Ahmadiyah Dalam Perspektif..., p. 155.

${ }^{68}$ Heather J. Sharkey, "Hassan Ahmed Ibrahim Sayyid Abd Al-Rahman al-Mahdi: A Study of Neo-Mahdism in the Sudan, 1899-1956", International Journal of Middle East Studies 38, no. 01 (February 2006): p. 154, https://doi.org/10.1017/ S0020743806342286.

${ }^{69}$ Delitzsch, Messianic Prophecies in Historical Succession ..., p. 15-16.

${ }^{70}$ Brisbois, "Millenarian Moderns: A Study of Utopian Desire" ..., p. ii and v. 
Prophet] Isa [Jesus] will descend and kill the Antichrist. Or, Isa will descend together with the Mahdi and help him kill the Antichrist. Such statements have been found in the hadith that religious leaders have published. ${ }^{71}$

With the information from the hadith of mahdawiyyah it would encourage radical activism groups to carry out attack against other religions. At a time when the condition of Muslims is increasingly difficult, while other religions experience glory, the spirit of mahdism is again presented to reclaim the glory of Islam. Mahdism in Islam is used as legitimacy to carry out violence and attack other groups that are considered to seize the right of Muslims. Islam is assumed to have higher position than other religions.

David Cook stated that with the existence of mahdawiyyah hadith, Islam has been transformed into a militant apocalypical movement that carries the idea of anti-christ. Cook further explained how radical Muslims, including the al-Qa'ida group, applied this idea to their agenda. ${ }^{72}$ In his other writings, Cook added that mahdism written in the hadith is the result of adoption of Christian apocalyptic literature. At first, Christians had tensions with Jews that encouraged them to make paranoid and sentimental ideas about Jews. In its development, these ideas were later adopted by Muslim authorities to instill sentiment to Christianity. They revised mahdawiyyah hadith many times in accordance with the conditions of the accompanying political conflict. In addition, the political conflict between Jews and Christians has a seizure setting over the Syrian territory, so that Islam also argued that the presence of the Mahdi would happen in that region. ${ }^{73}$ It is no wonder if annual conflicts often took palce in the area.

With all the features that are informed in the hadith, the presence of the Mahdi is to bring the "black flag" from the east, upholding Islamic sharia, eradicating tyrannies, destroying the cross and so on. This encourages every sect to immediately present the figure of the Mahdi. Indeed, there is no agreement on who the figure of the Mahdi is, but in fact

${ }^{71}$ Ibnu Khaldun, The Muqaddimah, vol. 11 (London: Trans. F. Rosenthal, 1958), p. 156; Murawiec, The Mind of Jihad..., p. 109; Cook, Contemporary Muslim Apocalyptic Literature..., p. 9.

${ }^{72}$ Cook, Contemporary Muslim Apocalyptic Literature..., p. 9-10.

${ }^{73}$ David Cook, "Hadith, Authority and the End of the World: Traditions in Modern Muslim Apocalyptic Literature", 2002, p. 51-53. 
each sect competes to show its existence by claiming that they are the revolutionary leaders. ${ }^{74}$ Ahmadiyah theology believes Mirza Ghulam Ahmad as a revolutionary figure, even confirmed him as a Prophet. ${ }^{75}$ Mahdis movement in Sudan claims Muhammad Ahmad b. Abdullah alMahdi, a descendant of the Messenger of Allah, as the promised Mahdi, ${ }^{76}$ even the position of the Mahdi in this perspective can be passed on, as to Abdurrahman the Mahdi. Local Islam in Java also adopted the idea of mahdism in the form of Ratu Adil and Satria Piningit. In the latest form of movement, ISIS claims that Abu Bakar al-Baghdadi is the leader and savior of Muslims'world, and will carry the flag for Isa al-Masih. ${ }^{77}$

With the inauguration of their figures as the Mahdi as well as the command to pledge allegiance to him precisely made the spirit to make a radical defense of him. Radical Islamic groups always aspire to uphold Islamic sharia as an effort to create socio-political change through violence and drastic ways. ${ }^{78}$ What happened was political tension. Radical activism has framed Islam within their ideological boundaries, literal interpretation, and political platforms so that they are unable to see, let alone understand, the truth of others. The change of Islam from religion to political ideology has indirectly reduced, amputated, and castrated the sublime messages of Islam in the Qur'an as a loving and tolerant universal religion into a narrow and rigid ideological Islam.

\section{E. Conclussion}

This paper finds out that the emergence of mahdism is due to the political crisis during the transition of power involving the Umayyad and the Abbasid dynasty. The Shi'a, as the oppressed group, carried out

\footnotetext{
${ }^{74}$ William F. Tucker, Mahdis and Millenarians: Shi'ite Extremists in Early Muslim Iraq (Cambridge: Cambridge University Press, 2008), p. xvi, https://doi.org/10.1017/ CBO9780511512094.

${ }^{75}$ Nahdi, Imam Mahdi Atau Ratu Adil? ..., p. 120.

${ }^{76}$ Linda Sayid Aḥmad Abdu al-Raḥmān Ṣādiq, Al-Śaurah al-Mahdiyyah Fī Syarqi al-Sudān (Khourtoum University, 2013), p. 1-2.

${ }^{77}$ Aaron Y. Zelin Washington Institute for Near East Policy, "Mengenal lebih jauh Abu Bakr al-Baghdadi, pemimpin Negara Islam", BBC News Indonesia, accessed 4 July 2019, https://www.bbc.com/indonesia/dunia/2014/07/140731_albaghdadi_ negara_islam.

${ }^{78}$ Afif Muhammad, Agama Dan Konflik Sosial; Studi Pengalaman Indonesia (Bandung: Marja, 2013), p. 63.
} 
resistance movements by creating apocalyptic ideas about the Mahdi through the mahdawiyyah hadith. The role and involvement of the Shi'a figures in the transmission of the mahdawiyyah hadith were able to influence the theological reasoning of the Muslim majority groups, allowing the milleniarian belief in the the Mahdi to grow strong among many, despite the epistemic problems.

However, in the current contexts, many Islamist groups are trying to realize the truth of mahdawiyyah hadith narrative in such a way that supports their claim over the milleniarian belief in their leaders as the Mahdi. When a crisis occurs, they use the mahdawiyyah hadith to gain political power under the pretext of upholding Islamic sharia, while implicitly suggesting an acknowledgement of their leaders as the Mahdi. Furthermore, together with the the Mahdi, the movements carried out an attack to other groups that are considered to have robbed the privilege of Islam. This is where mahdism becomes the root of radicalism in interfaith relations.

Theoretically, this paper contributes to the theorical debates about the emergence of hadith, which, in the case of the mahdawiyyah hadith, is strongly motivated by political events. These hadith are created to produce a political discourse as well as, used as a source of political legitimacy. Yet, even to this day, the practice of politicizing hadith remains common among Muslims. [.]

\section{References}

Abercrombie, Nicholas. The Penguin Dictionary of Sociolgy. England: The Penguin Books ltd., 1984.

Abu Dāwud, Sulaiman bin Dāwud al-Ṭayālisī al-Bașrī. Sunan Abū Dāwud. Edited by Muhammad bin Abdul Muḥsin al-Turkiy. Bab AlMahdi. Mesir: Dar Hijr, 1999.

Amidy, Tsamir Hasyim al-. Al-Mahdi al-Muntąār Fi Fikri al-Islām. Markaz al-Risalah, 1417.

Amin, Ahmad. al-Mahdi wa al-Mahdawiyah. Cairo: Muassasah Handawi li al-Ta’lim wa al-Tsaqafah, 2012. 
—_- Duha al-Islām. Vol. 3. Cairo: Maktabah al-Nahụah al-Mișriyah, n.d.

Aziz, Abdul. Varian-Varian Fundamentalisme Islam Di Indonesia. Jakarta: Diva Pustaka, 2004.

Aziz, M. Imam. 'Memahami Gerakan Islam: Sebuah Agenda Untuk Indonesia'. In Gerakan Sosial Islam: Teori, Pendekatan, Dan Studi Kasus, edited by Quintan Wiktorowicz. Yogyakarta: Gading Publishing, 2012.

Barakat, Halim. Dunia Arab; Masyarakat Budaya, Dan Negara. Translated by Irfan M. Zakie. Bandung: Nusa Media, 2012.

Brisbois, Michael J. 'Millenarian Moderns: A Study of Utopian Desire'. University of Chalgary, 2013.

Bukhārī, Abi Abdillah Muhammad bin Isma’il al-. Al-Jāmi' al-Ṣahīh Li alImām al-Bukhārī. Beirut: Dar Ṭauq al-Najāh, 1422.

Chon, Norman. 'Milleniarisme Zaman Pertengahan: Hubungannya dengan Studi Komparatif Gerakan-gerakan Millenarian'. In Gebrakan kaum Mahdi: studi tentang gerakan-gerakan keagamaan revolusioner, edited by Sylvia L. Thrupp, translated by Anas Muhyiddin. Bandung: Pustaka, 1984.

Cook, David. Contemporary Muslim Apocalyptic Literature. 1 edition. Syracuse, NY: Syracuse University Press, 2008.

- _ - "Hadith", Authority and the End of the World: Traditions in Modern Muslim Apocalyptic Literature', 2002, 31-53.

Delitzsch, Franz. Messianic Prophecies in Historical Succession. New York: Charles Scribner's Sons, 1891.

Fanani, Muhyar. Metode Studi Islam; Aplikasi Sosiologi Pengetahuan Sebagai Cara Pandang. Yogyakarta: Pustaka Pelajar, 2008.

Fathoni, Muslih. Paham Mahdi Syi'ah Dan Ahmadiyah Dalam Perspektif. 1st ed. Jakarta: Raja Grafindo Persada, 1994.

Filiu, Jean-Pierre. 'The Return of Political Mahdism', n.d., 15. 
Glock, Charles Y., and R. Stark. 'On the Origin and Evolution of Religious Groups (1965)'. In Sociological Perspective, Selected Reading, edited by Kenneth Thomson and Jeremy Tunstall. Middlesex: Penguin Education, 1979.

Graaff, Bob de. 'History of Fanaticism: From Enlightenment to Jihad', May 2010, 1.

Graff, Ronald Albert, and Lambert T Dolphin. Connecting the Dots: A Handbook of Bible Prophecy. Longwood, Fla.: Xulon Press, 2010.

Hardiman, F. Budi. Kritik Ideologi; Menyingkap Pertautan Pengetahuan Dan Kepentingan Bersama Jurgen Habermas. 2nd ed. Yogyakarta: Kanisius, 2004.

Humphreys, R. Stephen. Islamic History: A Framework for Inquiry. Revised edition. Princeton, N.J: Princeton University Press, 1991.

Ibnu Abi Syaibah, Abū Bakar al-'Abbasiy. Musannaf Ibnu Abi Syaibah. Edited by Kamal Yusuf al-Ḥūt. Riyaḍ: Maktabah al-Rasyd, 1409.

Ibnu Hanbal, Abu Abdullah Ahmad bin Muhammad al-Syaibāni. AlMusnad al-Imām Aḥmad Bin Hanbal. Edited by Syu'aib alArna'ūte. Beirut: Mu’assasah al-Risālah, 2001.

Ibnu Khaldun, Abu Zaid Abdur Rahman Ibnu Muhammad. AlMuqaddimah Li Ibnu Khaldūn. Edited by Abdullah Muhammad Darwis. Vol. 1. Bab Fī Amri al-Fāṭimī Wa Mā Yażhabu Ilaihi al-Nās Fī Sya'nihi. Damsiq: Dar Yu'rab, 2004.

Ibnu Majah, Abu Abdullah Muhammad bin Yazid al-Qazwini. Sunan Ibnu Mãjah. Edited by Muhammad Fuad Abdu al-Baqi. Bab Khurūj AlMahdi. Cairo: Dar Ihya al-Kutub al-Arabiyah, n.d.

Khaldun, Ibnu. The Muqaddimah. Vol. 11. London: Trans. F. Rosenthal, 1958.

Khuzai, Abu Abdullah Nuaim bin Hammad bin Muawiyah bin al-Haris al-. Kitāb Al-Fitan. Edited by Samir Amin al-Zuhairi. Vol. 2. Cairo: Maktabah al-Tauhid, 1412. 
Makin, Al. Nabi-Nabi Nusantara; Kisah Lia Eden Dan Lainnya. Yogyakarta: SUKA-Press, 2017.

Malik, Muhammad Mahjub. Al-Muqāwamah al-Dākhiliyyah Li Harakati alMahdiyyah. Beirut: Dar al-Jail, 1987.

McCharty, Thomas. Teori Kritis Jurgen Habermas. Translated by Nurhadi. Yogyakarta: Kreasi Wacana, 2008.

Muhammad, Afif. Agama Dan Konflik Sosial; Studi Pengalaman Indonesia. Bandung: Marja, 2013.

Murawiec, Laurent. The Mind of Jihad. 1 edition. Cambridge ; New York: Cambridge University Press, 2008.

Nahdi, Saleh A. Imam Mahdi Atau Ratu Adil? Jakarta: Arista Brahmatsya, n.d.

Nisāburi, al-Hākim al-, Abu Abdullah Muḥammad bin Abdullah. AlMustadrak 'alā al-Ṣahịhaini. Edited by Musțafa Abdul Qadir 'Ața. Beirut: Dar al-Kutub al-Ilmiah, 1990.

Nisāburi, Muslim bin al-Ḥajāj Abu al-Ḥasan al-Qusyairi. Al-Musnad alȘahīh al-Mukhtasar, Șahih Imam Muslim. Vol. 3. Bab Al-Imārah. Beirut: Dar Ihyā al-Turaṡ al-'Arabi, n.d.

Policy, Aaron Y. Zelin Washington Institute for Near East. 'Mengenal lebih jauh Abu Bakr al-Baghdadi, pemimpin Negara Islam'. BBC News Indonesia. Accessed 4 July 2019. https://www.bbc.com/ indonesia/dunia/2014/07/140731_albaghdadi_negara_islam.

Powers, David S. 'Law and Custom in the Maghrib, 1475-1500: On the Disinheritance of Women'. Law, Custom, and Statute in the Muslim World, 1 January 2007, 17-39.

- - - Studies in Qur'an and Hadith: The Formation of the Islamic Law of Inheritance. London: University of Callifornia Press, 1986.

Rahman, Fazlur. Islam. Chicago and London: University of Chicago Press, 1977. 
Razi, Abu Ja'far Muhammad bin Ya'qub bin Ishaq al-Kulaini al-. Al-Kāfi Li al-Kulaini. Edited by Ali Akbar al-Ghifari. Vol. 1. Teheran: Dār alKutub al-Islāmi, 1363.

Saritoprak, Zeki. 'The Mahdi Tradition in Islam: A Social-Cognitive Approach'. Islamic Studies 41, no. 4 (Winter 2002): 651-74.

Sayid Aḥmad Abdu al-Raḥmān Ṣadiq, Linda. 'Al-Śaurah al-Mahdiyah Fī Syarqi al-Sudān'. Khourtoum University, 2013.

Sharkey, Heather J. 'Hassan Ahmed Ibrahim Sayyid Abd Al-Rahman alMahdi: A Study of Neo-Mahdism in the Sudan, 1899-1956'. International Journal of Middle East Studies 38, no. 01 (February 2006): 153. https://doi.org/10.1017/S0020743806342286.

Sulaiman, Rusydi. Pengantar Metodologi Studi Sejarah Peradaban Islam. Jakarta: Raja Grafindo Persada, 2014.

Team, Drafting. The Holy Bible Sharif Translation. Beirut: Sharif Bible Society, 2006.

___. 'Vedas'. the Dharmic Scriptures Team, November 2002.

Thrupp, Sylvia L. 'Impian-impian Millenial di dalam Aksi: Laporan Mengenai Diskusi Konperensi'. In Gebrakan kaum Mahdi: studi tentang gerakan-gerakan keagamaan revolusioner, edited by Sylvia L. Thrupp, translated by Anas Muhyiddin. Bandung: Pustaka, 1984.

Tucker, William F. Mahdis and Millenarians: Shī 'ite Extremists in Early Muslim Iraq. Cambridge: Cambridge University Press, 2008. https://doi.org/10.1017/CBO9780511512094.

Wattimena, Reza. Melampaui Negara Hukum Klasik (Locke - Rousseau Habermas). Yogyakarta: Kanisius, 2007. 